\title{
A magyar fiatalok erősödő kivándorlási szándékának kiváltó okai és jellemzői
}

\section{Reasons and characteristics of the Hungarian youth's increasing emigrational intentions}

\author{
SISKÁNÉ SZILASI BEÁTA, HALÁSZ LEVENTE, \\ GÁL-SZABÓ LAJOS
}

SISKÁNÉ SZILASI Beáta: tanszékvezető egyetemi docens, Miskolci Egyetem, Műszaki Földtudományi Kar, Földrajz-Geoinformatika Intézet; 3515 Miskolc-Egyetemváros; ecobea@uni-miskolc.hu

HALÁSZ Levente: tudományos munkatárs, Miskolci Egyetem, Műszaki Földtudományi Kar, Földrajz-Geoinformatika Intézet; 3515 Miskolc-Egyetemváros; halaszlevente@hotmail.com GÁL-SZABÓ Lajos: tudományos segédmunkatárs, Miskolci Egyetem, Műszaki Földtudományi Kar, Földrajz-Geoinformatika Intézet; 3515 Miskolc-Egyetemváros; ecogszl@uni-miskolc.hu

KULCSSZAVAK: kivándorlás; migrációs potenciál; fiatalkorúak; területi egyenlőtlenségek

ABSZTRAKT: A magyar fiatalok egyre általánosabb életstratégiaként tekintenek a kivándorlásra, ami az országot továbbtanulás vagy munkavégzés céljából rövidebb, hosszabb időtávra elhagyók arányának drasztikus növekedésében követhető nyomon. Az írás az elmúlt évtized legfontosabb emigrációs jellegzetességeit taglalja, az országot elhagyó 18 és 40 év közöttiek fó emigrációs indokait keresi.

Nemzetközi és hazai szinten a migrációs folyamatok, azok meghatározó mechanizmusai a tudományos érdeklődés középpontjába kerültek, a kivándorlást magyarázó objektív és szubjektív adatokra egyre nagyobb igény mutatkozik. Ennek érdekében a 2013 és 2016 között közel 10000 fó megkérdezésén alapuló kérdőíves adatgyűjtés eredményeinek feldolgozásával bemutatjuk a kivándorló fiatalok legfontosabb demográfiai jellemzőit, azok évtizedes arányeltolódásait, az emigráció trendjének változásait, a kivándorláshoz vezető taszító és vonzó tényezőket, a migrációs potenciál országon belüli (város-vidék dualitás) és intraregionális egyenlőtlenségeit.

Beáta SISKÁNÉ SZILASI: associate professor, head of department, Institute of Geography and Geoinformatics, Faculty of Earth Science and Engineering, University of Miskolc; H-3515 Miskolc, Hungary; ecobea@uni-miskolc.hu

Levente HALÁSZ: research fellow, Institute of Geography and Geoinformatics, Faculty of Earth Science and Engineering, University of Miskolc; H-3515 Miskolc, Hungary; halaszlevente@hotmail.com Lajos GÁL-SZABÓ: junior research fellow, Institute of Geography and Geoinformatics, Faculty of Earth Science and Engineering, University of Miskolc; H-3515 Miskolc, Hungary; ecogszl@uni-miskolc.hu 
KEYWORDS: emigration; migration potential; Hungarian youth; spatial inequalities

ABSTRACT: Younger Hungarian generations consider emigration as an alternative life strategy that seizes the opportunity of studying in foreign higher educational institutions or being employed in the receiving countries' labor markets for short, medium or long periods. During the previous decade (since the EU accession) the proportion of Hungarian emigrants radically increased which directed the attention of international and national scientific bodies and policymakers towards the phenomenon. Recent studies shed light on the most significant mobility characteristics of the last 10 years and put special emphasis on the youth (age 18-40) as the most affected age group. The migration process, its influencing social, economic, political, cultural mechanisms, and the explanatory factors are in the limelight of many inter-and multidisciplinary research. The demand is increasing on objective and subjective data in terms of migration potential and emigration trends. This particular need led to a 4-year-long project entitled "Recent trends of Hungarian emigration" realized between 2013 and 2016, focusing on Hungarians living in Hungary, but aiming to emigrate, as well as Hungarians already settled abroad. Almost 10000 respondents were surveyed in Hungary, 245 people in the diaspora, and semi-structured interviews were prepared both in Hungary and abroad. Targeted questions aimed at getting to know the specificities (duration, determination, target country, etc.) of their migration potential, the reasons behind the definite decisions, the recent status quo and the changes of their demographic features in detail. This paper concentrates on the younger generations which represented $49 \%$ of the total number of respondents.

After the political regime change, the pace of migration was not as fast as it is nowadays. According to numerous official Hungarian and foreign statistical data sources, 300-650 000 Hungarians are living or studying abroad primarily in Western and Northern European highly developed countries such as the United Kingdom, Germany, Austria, Sweden, Switzerland and the Benelux states. The average age of migrants is 29-30, although, year by year, younger generations tend to leave Hungary for shorter or longer periods. In 2016 no distinction could be made between the number of migrant men and women in this respect. Based on our empirical results, we proved a "sinister" phenomenon: the strength of migration potential and the length of foreign stay correlate. People have weak migration intentions, aim to stay abroad only for a short or intermediate period, although the seriousness of their decisions is fragile. Hungarian youngsters, on the other hand, with severe decisions on emigration, aim to leave the country for longer periods or even forever which is appalling in prospect and claims urgent policy interventions.

Migration potential is selective: the most affected social groups are those for which opportunities (youngsters, having massive and diverse human capital, adventure-seekers) and constraints (dissatisfied, pessimistic, discriminated social strata) strengthen each other. Crucial push factors are low macroeconomic performance, individual financial problems, depth crisis, loan re-payment impossibility, lack of adequate jobs, disillusionment from politics, uncertainty in future and social conflicts. On the contrary, the developed economic structure, the variety of workplaces and higher educational institutions, inclusive society, the quality of nature, mentality of people turned to pull factors.

Sharp migration potential inequalities emerged between Budapest (having the highest ratio of youngsters intending to leave or have already left) and the rural countryside. In addition, residents most eager to migrate live in post-industrial socialist cities, areas gone through unsuccessful economic transition, underdeveloped rural neighborhoods near the Eastern and Southern borders and in counties characterized by high proportion of Roma people. Less affected areas are the Western borderland (nota bene, the daily commuting of around 30-40 000 people to Austria and Slovakia "substituting" emigration) and the developed rural countryside where many people are employed by the agricultural sector.

One of the most urgent challenges of Hungary burdened with a great multitude of structural difficulties (aging, lower fertility rate, educational attainment lagging behind the EU, labor market imbalance, spatial-social polarization, etc.) is to halt/decelerate emigration. Policymakers must make profound and effective interventions in order to improve life perspectives and diminish uncertainty about the future, in particular for the most vulnerable lower and middle strata Hungarian youngsters. 


\section{Bevezetés}

1989 óta a magyar társadalom egyre intenzívebben vesz részt a nemzetközi migrációs folyamatokban. A '90-es évek elején jellemző nagyarányú bevándorlással párhuzamosan az új évezred elejétől felgyorsult a nyugat- és észak-európai országok, valamint a világgazdaság erőcentrumai (pl. Egyesült Államok, Távol-Kelet, Perzsa-öböl térsége) felé irányuló kivándorlás, amely egyre nagyobb számban és arányban jelenik meg a statisztikákban és az empirikus vizsgálatokban (Blaskó, Sik, Ligeti 2014; Hárs 2016; Sik 2015). A 2004-es európai uniós csatlakozásig lassú, azóta viszont gyors ütemben növekszik az országot rövidebb-hosszabb időre elhagyó magyar állampolgárok száma, akik főként az Európai Unió gazdasági és társadalmi téren fejlettebb országainak munkaerőpiacai felé áramlanak. A 2007-es schengeni határnyitás, a 2008-ban kezdődött globális válság következtében erősödő munkaerőpiaci problémák, a 2000-es évekhez képest kiugróan magas, csaknem 11\%-ot elérő munkanélküliség (emellett a fiatalkorúak háromszor magasabb munkanélküliségi rátája: 2012-ben 27,9\%), a beszűkülő életstratégiák, végül a 2011. május 1-jével megnyíló német és osztrák munkaerőpiac kínálta lehetőségek látványosan gyorsították és gyorsítják jelenleg is a folyamatot. Hangsúlyozandó, hogy a magyarok esetében döntően gazdasági, kisebb arányban szociokulturális és földrajzi-történelmi tényezők magyarázzák a migráció erősödését. Az ország jövője tekintetében több szempontból is (demográfiai erózió, a születések számának csökkenése, a szociális, oktatási és egészségügyi ellátórendszerek hiányosságai, a nyugdíjrendszer jövőbeni konszolidálása, a deprivált társadalmi csoportok növekvő aránya, a falusi térségek kiüresedése stb.) még problematikusabbá teszi a jelenlegi és a jövőbeni állapotot, hogy a leginkább érintett korcsoportok egyre fiatalabbak: napjainkban az emigránsok átlagos életkora 29-30 év - derül ki mind az általunk végzett, a SEEMIG, a MOVE és a KSH kurrens kutatásainak eredményeiből. A dilemma nem Magyarország-specifikus, számos kelet-, közép- és dél-európai ország küzd hasonló vagy még intenzívebb ütemủ elvándorlással.

Jelen kutatás 2013 végén indult, ez az év tekinthető - a statisztikai adatok és az empirikus vizsgálat alapján - a legintenzívebb kivándorlási szakasz kezdetének. Az azóta eltelt csaknem fél évtized tudományos alapot biztosít annak bemutatásához, vajon miként alakult és fog alakulni az emigráció, valamint milyen társadalmi-gazdasági következmények kísérték eddig és fogják jellemezni ezt a folyamatot elsősorban a fiatal, 18 és 40 év közötti korcsoportokban. A jelen- és jövőbeli folyamatok felméréséhez nagyban hozzájárul a kivándorlási szándék mélyreható vizsgálata.

A magyarok emigrációjával kapcsolatos kutatások számos kérdésben hasonló eredményekre jutottak az érintett korcsoportok, a célországok és az okok kapcsán (Blaskó, Gödri 2014; Gödri 2015; Hárs 2011; Hárs, Simon 2015). A KSH adatai szerint a migráns magyarok 44\%-a 30 év alatti, 77\%-a a 40. életévét még nem töltötte be. 2009-től gyakorlatilag évente duplázódik a fiatalkorú emigrán- 
sok száma, 2015-ben tízből nyolc kivándorló ebből a korcsoportból érkezett (Blaskó, Gödri 2014; Blaskó, Sik, Ligeti 2014), így egyre vészjóslóbb mértéket ölt a fiatalok exodusa. A jövővel kapcsolatos bizonytalanság, az oktatáspolitikával és szociális ellátórendszerrel szembeni növekvő elégedetlenség a migrációt erősítő motivációk. A felsőoktatási reformok, valamint a külföldi tanulás lehetőségeinek adminisztratív megkönnyítése miatt évről évre (az elmúlt évtizedben negyedével) csökken a magyar egyetemekre és föiskolákra jelentkező magyar állampolgárságú hallgatók száma. Az oktatási célú kivándorlás jelentőségét bizonyítja, hogy 2015-ben a gimnazisták 50-60\%-a orientálódott külföldi felsőoktatási intézmények felé sőt, az elitgimnáziumokban tanulók számára léteznek olyan szakmaterületek (pl. közgazdaságtan, nemzetközi kapcsolatok), amelyek iránt érdeklődők 95\%-a tervezte a külföldi egyetemeken való továbbtanulást (Melegh 2002; Vas 2015). Az Aktív Fiatalok Magyarországon Kutatócsoport 2015-ös jelentése szerint 8-10 000 magyar diák (hallgató) tanul külföldi felsőoktatási intézményben. Ez a szám nem tartalmazza a hallgatói mobilitási programok (pl. Erasmus+) keretében tanuló diákokat, Erasmus hallgatói célú mobilitási ösztöndíjjal évente 4-5000 magyar hallgató jut külföldi felsőoktatási intézményekbe. A kint tanulók nagy számban szerzik a fogadó országokban első munkatapasztalataikat, valamint a nemzetközi környezetben történő szocializáció, a kiépített kapcsolati háló, a magas szintủ idegen nyelvi és interperszonális kompetenciák erősítik a későbbi (akár végleges) kivándorlási szándékot. ${ }^{1}$

A legfiatalabb (25 év alatti) korosztály kivándorlása és vándorlási szándéka mögött számos tényező áll: többek között az erősödő Magyarország-kritika, a magas színvonalú oktatás és nemzetközi tapasztalatszerzés iránti igény, a nyelvtanulás, a lehetőségek bősége, a kalandvágy - igaz, egyre kisebb mértékben. Minden második vagy harmadik diák a hazaköltözés mellett dönt a tanulmányai befejezését követően, ezt olyan szubjektív tényezők magyarázzák, mint például a Magyarországon élő közeli családtagok és barátok vagy a hazai lakókörnyezet. A legfontosabb tény azonban a fiatalok utóbbi években fokozódó külföldi munkavállalási szándékának növekedése, amely számos kutatásban igazolást nyert (Kóródi, Siskáné Szilasi 2016; Rohr 2012). Jelen tanulmányunkban a 2013-2016 között készült vizsgálatban részt vevő, 18 és 40 év közötti magyarok kivándorlási szándékát mutatjuk be.

\section{Migrációs elméletek, a kivándorlást befolyásoló tényezők időbeli változása}

A migráció szelektív folyamat, amelyet a kor, a nem, a társadalmi-jövedelmi státusz, a kvalifikációs szint, emellett számos „puhább” tényező (pl. a szocializációs háttér, a befogadó társadalomról kialakított kép és meglévő tudás, a belső értékrend, a családi kötelék) befolyásol. A 20. század migrációs folyamatait 
három fó elmélet magyarázza. 1. A neoklasszikus gazdasági teória (Sjaastad 1962; Todaro 1969) értelmében a globális vándorlási folyamatok a munkaerő világméretű keresleti és kínálati rendszeréhez köthetők. A munkaerőhiánnyal küzdő fejlett országok relatíve magasabb bérekkel csábítják az alacsonyabb fejlettségi fokon lévő nemzetek aktív korú lakosait. 2. A szegmentált munkaerőpiac (Piore 1979) elmélete globális és kontinentális szinten a kapitalista országok által kiépített duális gazdaságokat hangsúlyozza a munkaerő erősödő migrációjának okaként. A fejlődésben elöl járó államok elsődleges piaca a magas presztízsű biztonságos munkát, munkakörülményeket keresők számára, míg másodlagos piaca az alacsonyabb kvalifikációval rendelkezők számára biztosít elhelyezkedési lehetőséget. 3. Saskia Sassen (1988) világrendszer-elmélete szerint a nemzetközi migráció a globális kapitalizmus mellékterméke. A posztindusztriális fejlődés strukturális gazdasági problémákat generált, amelyek taszító tényezőkként jelennek meg a fejlődő (fél)periféria országainak lakói számára és egyre nagyobb tömegek választják a fejlett gazdaságú magterületeket hosszú távú letelepedésre. Az újabb elméletek szerint (Massey et al. 1993) a migrációs mozgást nemcsak a hálózatok bővülése és a migránsokat támogató intézmények fejlődése, hanem az is fenntartja, hogy a további mozgások valószínűsége időben előrehaladva folyamatosan nő. Az indítékok összegződnek, amikor minden egyes migrációs művelet módosítja azt a társadalmi összefüggést, amelyben a következő, migrációra vonatkozó döntést meghozzák, méghozzá úgy, hogy nő a további migráció valószínűsége. Ezt a folyamatot nevezik kumulált okságnak.

A Magyarországról az EU fejlett államaiba kivándorlók pontos számáról csak becslések láttak napvilágot. A statisztikai bizonytalanságot alátámasztja a magyar és külföldi tükörstatisztikák (pl. Eurostat, Destatis, Statistik Austria stb.) számadatai közötti látványos különbség: a jelenleg kint élő és munkát vállaló, 1989 óta emigrált magyar állampolgárok száma minimum 350 000, maximum 600000 fó.

Annak ellenére, hogy Kelet- és Közép-Európa posztszocialista országai közül - az Eurostat adatai tükrében - arányait tekintve máig Magyarországról emigrálnak legkevesebben, a folyamat nagyságrendi növekedése és a migrációt erősítő számos ok folyamatos fennállása súlyos szociális, demográfiai és gazdasági eróziót sejtet. A KSH és a SEEMIG kutatásai szerint 2014-ben 31500 magyar távozott legalább egy évre külföldre, ez másfélszer annyi, mint 2013-ban és hat és félszer több, mint 2009-ben.

A teljes migrációs potenciált vizsgálva Magyarország uniós integrációja óta alapjaiban megváltoztak az emigránsok szociodemográfiai és jövedelmi státuszbeli jellegzetességei. Egy évtizede a kivándorlás mellett döntők között lényegesen nagyobb hányadot tettek ki a férfiak, a 30 év alattiak aránya eltörpült a 30 és 40 éves korú emigránsokhoz képest, nagy számban mutattak migrációs hajlandóságot a munkanélküliek, a roma népességhez tartozók és a Nyugat- és Északnyugat-Magyarországon élők. A humán tőkén belül kiemelkedő jelentőséggel bírt az idegen nyelv használói szintű tudása, valamint a korábbi külföldi 
tanulmányok vagy munkatapasztalat is bátorítólag hatott a további emigrációra (Hárs, Simonovits, Sik 2004). Ekkor még a kalandvágyélmény is fontos faktornak számított; napjainkban, amikor másfél hét alatt el lehet intézni a külföldi munkavállalást (munkahely, szállás, költségterv), ez az attitűd eltűnni látszik.

\section{A kutatás módszertana}

A 2013 őszén indult OTKA-kutatás az elmúlt nagyjából másfél évtized kivándorlási trendjeinek alakulását vizsgálja. A kvantitatív és kvalitatív elemeket is tartalmazó vizsgálat három adatfelvételi pilléren áll. Az első mintavétel 9876 fö (6503fős föminta és 3373 fös részminta) megkérdezésén alapul. A magyarországi adatbázis online és terepi kérdőíves adatgyüjtés felhasználásával készült, a felvételezés a kivándorlási szándékra, a szándék erősségére, komolyságára, a háttérben meghúzódó okokra fókuszált. Hangsúlyozandó, hogy a megkérdezettek harmadát (részminta) 34 magyarországi felsőoktatási intézmény 18 és 40 év közötti hallgatói alkotják. A főmintában a megkérdezettek 65,8\%-a a lekérdezés eszmei időpontjában a megyei jogú városok lakója. Közülük a randomizálás szabályainak megfelelve egyszerü véletlen mintavétellel minden 1000. embert kérdeztek meg a kutatás kérdezőbiztosai. A mintavétel több lépcsőben történt, rétegzett valószínűségi mintavétellel. Első lépcsőben a vizsgálandó települések körét határoztuk meg, így került Budapest, a megyei jogú városok ( $23 \mathrm{db}$ ), valamint a felvételezés időpontjában ott tartózkodó, de vidéki címmel rendelkező magyar állampolgárok lakóhelyei (ezeken belül települési jogállás szerint két csoportot alkottunk: vidéki városok és falvak) a mintába. A második lépcsőt a kiválasztott településen élő olyan 18-65 év közöttiek alkották, akik Magyarországon állandó lakóhellyel rendelkeztek a mintavétel idején (a 2013-as és 2014-es évben).

$\mathrm{Az}$ alapsokaság leképezi az ország településstruktúráját régiók és településnagyság szerint. A kérdezőbiztosok a megyei jogú városokban mind az ott állandó lakhellyel rendelkezőket, mind a kérdezés során ott tartózkodó, vidéki lakcímmel rendelkezőket bevonták a felmérésbe. A terepmunkát papíralapú próbakérdezéssel indítottuk, amelynek tapasztalatai alapján készült el a végleges kérdőív. Az esetleges hibákat pótlekérdezéssel korrigáltuk. A terepmunkát követően a mintamegoszlástól való eltéréseket súlyozással javítottuk. A súlyozást nemre, korcsoportra, a települések állandó népességszámára és iskolai végzettségre végeztük el. A kiegészítő kutatásban (a felsőoktatási intézmények tanulói által alkotott részminta) a 18 és 40 év közötti korosztályra összpontosítottunk, akik önkéntesen töltötték ki a kérdőíveket, így ez a mintavétel nem reprezentatív. Felmérésükkel célunk a fiatalok kivándorlási szándékának részletesebb vizsgálata, így a teljes, közel 10000 fős mintából leszürtük a 18 és 40 év közöttieket (ide tartozik egyrészt a felsőoktatási részminta, másrészt a fömintából a „tanuló” gazdasági státuszú megkérdezettek, összesen 4806 fö). 
A másik adatgyűjtés a jelenleg külföldön élő (ott tanuló és/vagy dolgozó) magyarokat célozta meg. A kérdőívet főként a külföldi életminőséggel, boldogulással, jövőbeli tervekkel, a hazaköltözés feltételeinek feltérképezésével bővítettük. Az online kérdőívet elsősorban a magyarok számára legfontosabb célországokban élő 245 fö töltötte ki.

Előbbieken túl a kutatás eredményeinek árnyalása végett 2016 és 2017 folyamán 56 félig strukturált mélyinterjút készítettünk. A felmérésben részt vevő emigráns magyarokat hólabdamódszerrel értük el. Az interjúk döntően a legfőbb migrációs centrumokban élő magyar diaszpórákra koncentráltak, ezáltal a kapcsolati hálókat, a migrációs burok jellegzetességeit is megvizsgálhattuk.

Az eredményekből e lapszám másik tanulmányában (Siskáné Szilasi, Halász, Vadnai 2017) a kint élő magyarok életminőségét, a beilleszkedés gyorsaságát, a magyarok közötti kapcsolati háló jellegzetességeit, a célországok specifikumait és a remigráció valószínűségét elemezzük.

\section{A fiatalok kivándorlási szándékának jellegzetességei és fő motivációforrásai}

\section{A kivándorolni szándékozó fiatalok demográfiai jellemzői}

Az utóbbi évek kivándorlási folyamataival foglalkozó kutatások rámutattak arra, hogy a 2000-es években tapasztaltakkal ellentétben a nemi megoszlásban elhanyagolható férfitöbblet jellemző (Blaskó, Gödri 2016). A fiatalos mintánkban nőtöbblet (férfi 40,1\%, nő 59,7\%) mutatható ki a válaszadók között (Magyarországon 2011-ben férfi: 47,5\%, nő: 52,5\%), mégis megállapítható, hogy a nők közel azonos arányban szándékoznak kivándorolni, mint a férfiak, viszont nagyobb arányban is térnek vissza rövidebb-hosszabb külföldi munkavégzést követően.

A kutatásunkban a kivándorlási szándékot a „Tervezi-e az elkövetkező egykét évben, hogy külföldre megy munkavállalás céljából?" kérdéssel vizsgáltuk. A kérdés ilyen megfogalmazása a terv és a szándék mérése szempontjából szigorú változatnak tekinthető (Sik, Szeitl 2016). A kutatás belső érvényességének javításához - tehát a migrációs szándék komolyságának mérésére - számos szürű funkciójú, kiegészítő kérdést integráltunk. Ezek közé tartozik például: munkavállalás vagy tanulási cél áll-e a migrációs szándék mögött; rövid vagy hosszú távra, esetleg örökre tervezi a kivándorlást; mely országba, régióba, településre költözne. Ezáltal szétválasztható a biztos szándékkal bírók és az „álmodozók”, latolgatók csoportja. A szándékot tekintve a „nem tervez kivándorlást” kategóriában közel azonos nemi megoszlást (férfi: 42,6\%, nő: 43,3\%) kaptunk. Mindkét nem gyakorlatilag ugyanolyan arányban rendelkezik kevésbé határozott szándékkal (férfi: 37,8\%, nő: 36,9\%). A határozott szándék (,igen, készül kimenni”) 
már teljesen azonos nem arányokat (19\%) mutatott. Hangsúlyozandó, hogy a kivándorlás mellett döntő nők nagyobb arányban nem függetlenek, hanem párral, gyermekekkel, családtagokkal közösen hagyják el az országot és számukra lényegesebb a fogadó országban már kialakított kapcsolati háló (Knörr 2000). Sőt, egyre több esetben párjuk után költöznek, a külföldi egzisztenciális bázis megszilárdítását követően.

Összességében kutatásunk alátámasztja, hogy az utóbbi években a nők kivándorlásban való részvétele az előző időszakokhoz képest növekedett. A jelenség több tényezővel magyarázható, egyrészt a nők társadalmi megítélésének és szerepvállalásának változásával (egyéni karrier, munkaerőpiaci státusz, családi elvárások), másrészt a kapcsolati háló bővülésével, harmadrészt az intézményi rendszer erősödésével, amely a külföldi munkavállalás megbízhatóságát és biztonságát is növelte.

1. ábra: A válaszadók kivándorlási szándék és korcsoport szerinti megoszlása ( $\mathrm{N}=4806)$ Proportion of different age-groups in light of emigration intention ( $N=4806)$

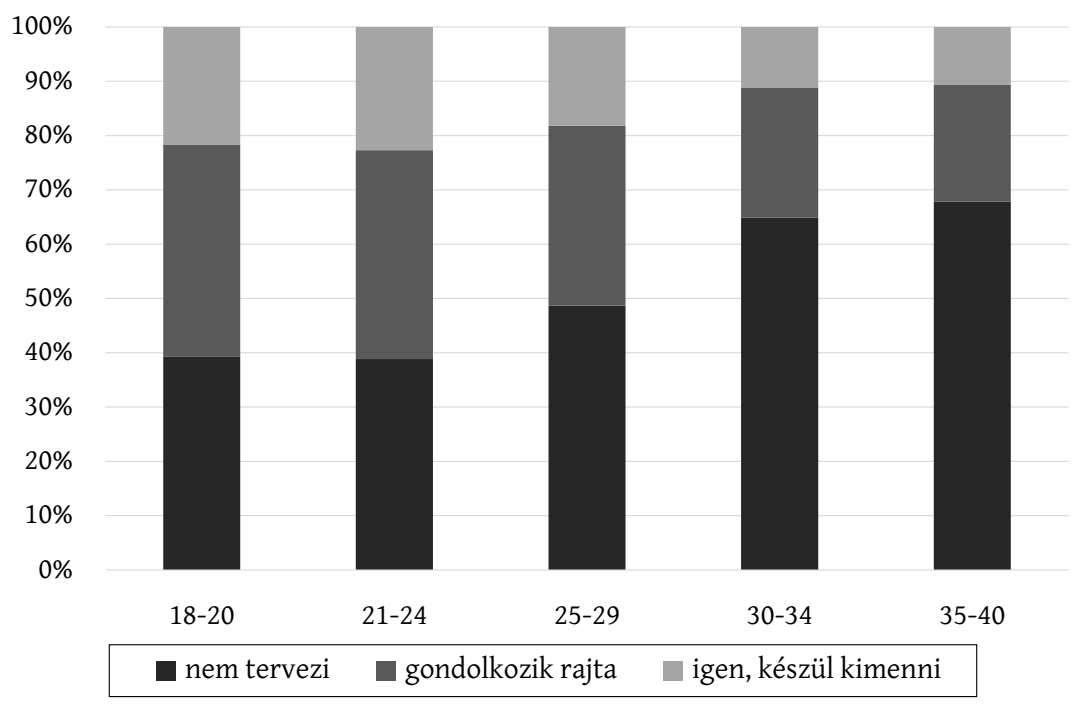

A fiatal korcsoportok erősebb kivándorlási szándékkal bírnak (1. ábra). Egyértelműen meghatározható, hogy a komoly (tervezett) kivándorlási szándék a 20-29 évesek esetében a legnagyobb arányú. Szociális és demográfiai szempontból vészjósló, hogy egyre fiatalabb korosztályba tartozók - elsősorban a húszas éveik elején lévők - szándékának komolysága erősödik. A harmincas korcsoport esetében egyrészt magasabb a családjuk, a kiépített egzisztencia, a kudarctól, a bizonytalanságtól való félelem miatt itthon maradók aránya, ezzel szemben a komoly szándékkal rendelkezők száma is kiemelkedő a hezitálók csapatával összevetve. Összességében a 18-40 év közöttiek esetében a tervezett, komoly kivándorlási szándék 5-25\% között határozható meg. Az összesített 
szándék (bizonytalan és határozott terv) a vizsgált korcsoportnál csak néhány esetben (31-34, 37-38, valamint a 40 évesek) esik 50\% alá. Az ország jövője szempontjából kiemelt kérdés, hogy a szándékból milyen arányú lesz a megvalósulás, valamint az is, hogy a tényleges kivándorlók milyen arányban fognak visszatérni.

\section{A kivándorlási szándék erőssége és időtartama}

A kivándorlási szándék meghatározása nem egyszerű (Gödri, Feleky 2013), a jövőbeni várható mozgások becslésére jelen kutatás eredményei is csak érintőlegesen használhatóak, inkább olyan korai előrejelző információt adnak (Sik, Szeitl 2016), amely alapján a várható szándék intenzitását, esetleges megvalósulását ismerhetjük meg.

A kérdőíves kutatás során az 1. ábra három kategóriáját kiegészítő kérdésekkel pontosítottuk, melyek a helyre és időtartamra vonatkoztak. A tervezett munkavállalás időtartamát négy csoportra bontottuk (2. ábra).

A szakirodalom a migráció típusait három kategóriába sorolja (rövidebb és hosszabb távú külföldi munkavállalás, valamint végleges kivándorlás), amelyek együttesen a halmozott migrációs potenciált adják (Gödri, Feleky 2013). Az adatbázisunk elemzése során azonban olyan markánsan jelent meg az 1-5 éves munkavállalási terv, hogy elkülönítettünk egy „középtávú” kategóriát is. A rövid távú (1 évnél rövidebb) munkavállalók körében magasabb a bizonytalan, mint a határozott szándékkal bírók aránya (9,7\%;12,1\%). A középtávra tervezők

2. ábra: Migrációs hajlandóság a kivándorlási szándék határozottsága és a külföldi munkavállalás tervezett időtávja szerint ( $\mathrm{N}=4806)$ Migration potential according to emigrants' intentional determinacy and the planned mobility duration $(\mathrm{N}=4806)$

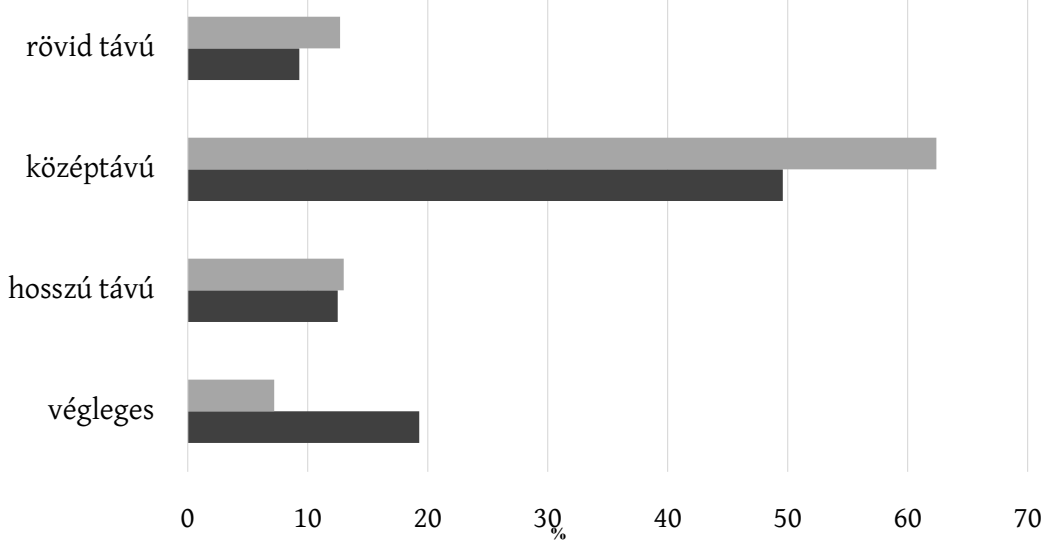

bizonytalan szándék @ határozott szándék 
esetében is jelentősebb (62\%) a bizonytalanok csoportja. A migrációs szándék a még szüleikkel élő diákok (fiatalok) és a munkanélküliek körében erős, azonban a megvalósulásig ritkán jut el. A hosszú távra tervezőket, illetve a véglegesen kivándorlókat vizsgálva a határozott szándékkal bírók aránya meghaladja a bizonytalanokét. A megvalósuláshoz leginkább közel álló kivándorlási szándékkal a két utóbbi távra tervezők rendelkeznek, akik az adatbázisunkban a 18-40 éves korcsoport 26,1\%-át adják. 4 éve zajló vizsgálataink alapján a határozott szándékú migráció aránya nő, a megkérdezettek egyre fiatalabb korban tesznek szert első külföldi munkatapasztalataikra, a már önállóan élő, magukat anyagilag fenntartó fiatalok migrációs hajlandóságának határozottsága pedig egyre szilárdabb és lényegesen hosszabb távú (akár teljes élethosszra vonatkozik).

\section{A kivándorlási szándékot és a célországválasztást befolyásoló tényezők és földrajzi megoszlásuk}

Kutatásunkban megvizsgáltuk a kivándorlási szándékot és a célországválasztást meghatározó vonzó és taszító tényezőket (1. táblázat). A taszító tényezőket vezető anyagi, gazdasági elégedetlenség globálisan is az emigrációt magyarázó fó ok. A megkérdezett magyar fiatalok esetében egyrészt az ország makrogazdasági helyzete, a 2010 óta gyakorlatilag stagnáló GDP, a növekvő inter- és intraregionális egyenlőtlenségek, másrészt egyéni szinten az alacsony reálbérek, ${ }^{2}$ a főként alacsony és közepes státuszúakat érintő adósságcsapda, ${ }^{3}$ a megtakarítások hiánya a legfőbb, migrációs hajlandóságot erősítő tényezők. A végzettségnek megfelelő, versenyképes bért nyújtó, rugalmas (pl. távmunka engedélyezése) munkahelyek hiánya a másik legfőbb, kivándorlásra késztető indok. A közel 4 éves kutatás során tapasztalataink alapján megnőtt a jelentősége a politikai klíma kritikájának, a kilátástalan, a túlélésért való folyamatos küzdés miatti bizonytalan jövőnek és az életszínvonal csökkenésének. Az általános elégedetlenség növekedését számos független nemzetközi összehasonlító felmérés is alátámasztja: a világdemokráciai vizsgálat (World Democratic Audit - http://www.worldaudit.org/democracy.htm) 2016-os eredményei szerint hazánk 154 ország közül a 44. (Jordánia és Románia között található), az élettel való megelégedettség rangsorában a 107. (Gambia és Líbia között). Az OECD 38 országát vizsgáló Better Life Index Magyarországot a 32. helyre sorolja, Görögország és Oroszország közé. Növekvő jelentőségű taszító faktorként jelentkezik a mentalitással kapcsolatos elégedetlenség és a társadalmi értékválság, a múltba révedő, a folyamatos anyagi és egzisztenciális küzdelmek miatt a közösségek és egyéni életstratégiák terén is cselekvésképtelenné váló, egyre szélesebb társadalmi rétegek kialakulása.

A társadalmi tőke bizonyos elemei jelentős mértékben növelik a migrációs szándékot. A humán tőkén belül ilyen az idegennyelv-ismeret, a korábbi külföldi munkaerőpiaci tapasztalat és az egyén hazához való gyenge kötődése (Castles, Miller 2003; Sik, Örkény 2003). Érdekes módon az egyik fó vonzó tényező - a tár- 
1. táblázat: A kivándorlási szándékot és a célországválasztást meghatározó vonzó és taszító tényezők (az említés \%-ában)

Push-pull factors influencing target countries choice

\begin{tabular}{lr|lr}
\hline \multicolumn{1}{r}{ Taszitó tényezók } & $\%$ & \multicolumn{1}{|c}{ Vonzó tényezők } & $\%$ \\
\hline Gazdasági, anyagi problémák & 39,4 & Gazdasági, anyagi tényezők & 35,3 \\
Megfelelő munkahely hiánya & 20,5 & Minőségi munkahely & 14,3 \\
Politikai helyzet & 8,2 & Tapasztalatszerzés & 9,8 \\
Bizonytalan jövő & 7,9 & Nyelvtanulás & 6,1 \\
Mentalitás & 6,2 & Mentalitás & 6,1 \\
Életszínvonal & 6,1 & Természeti környezet & 4,2 \\
Társadalmi konfliktusok & 5,1 & Megbecsültség & 4,1 \\
Alacsony megbecsültség & 4,6 & Perspektivikus jövő & 3,8 \\
Egyéb tényezők & 1,4 & Társadalom & 3,4 \\
\hline
\end{tabular}

sadalmi hálózatok formálódása - marginális tényezőként jelentkezik az általunk vizsgáltak percepciójában, pedig nélkülözhetetlen szerepet tölt be a munkalehetőségek felkutatása és az anyagi támogatás terén, de megkönnyíti a külföldi közösségekhez való integrációt és bátorítólag hat a vállalkozásindításra. Kutatásunk érdekes eredménye, hogy meglepően sok, elsősorban az észak-európai államokba és a nyugat-európai országok vidéki térségeibe igyekvő fiatal számára a minőségi természeti környezet vált az egyik legfontosabb befolyásoló tényezővé.

A tényezőket összegezve a Lee (1966) által lajstromba vett fó taszító indokok közül az egészségüggyel, a lakhatással (pl. szociális bérlakások hiánya) és az esélyegyenlőséggel kapcsolatos ellenérzéseken kívül a magyar fiatalokat a globális okokhoz hasonlatos faktorok késztetik-kényszerítik az ország elhagyására. A vonzó tényezők közül a jobb egészségügyi, szociális és oktatási rendszer iránti vágy a magyar fiatalok percepciója szempontjából nem jelent meg lényeges motivációként, viszont a többi felsorolt befolyásoló indok - kisebb-nagyobb arányeltolódásokkal - egybeesik a világszinten általánosan tapasztalt tényezőkkel.

Az elmúlt két évtizedben a magyar fiatalok által preferált, fóként nyugatés észak-európai célországok területi képe nagyrészt változatlan, azonban a 2011 májusában megnyitott német és osztrák munkaerőpiac addig nem látott tömegek munkavállalásához és a területi arányok változásához vezetett. Jelenleg Németországba és az Egyesült Királyságba érkezik a legtöbb magyar fiatal, valamint a még itthon élő megkérdezettek körében is ez a két állam vezeti a legkedveltebb országok rangsorát (3. ábra). Ezekben az esetekben az emigráció fó célterületei nagyvárosok és azok agglomerációi: az Egyesült Királyságban az oxfordi székhelyü Migration Observatory számításai szerint csaknem „Székesfehérvárnyi”, tehát 96000 magyar él (Vargas-Silva 2017). Ausztria áll a harmadik helyen, azonban az oda naponta, hetente ingázó csaknem 35000 magyar munkavállaló és tanuló torzítja az arányt. Nyugati szomszédunk munkaerővonzó területe gyakorlatilag egész Magyarország területét lefedi, a heti gyakoriságú ingázásban egyre növekvő szerepet tölt be az alföldi városok (pl. Nyíregyháza, Mátészalka, Békéscsaba) aktív korú népessége (Kiss, Szalkai 2014). 
3. ábra: A magyar fiatalok kivándorlásának és migrációs szándékának fö célországai (a válaszok \%-ában)

Main target countries of Hungarian youth intending to emigrate
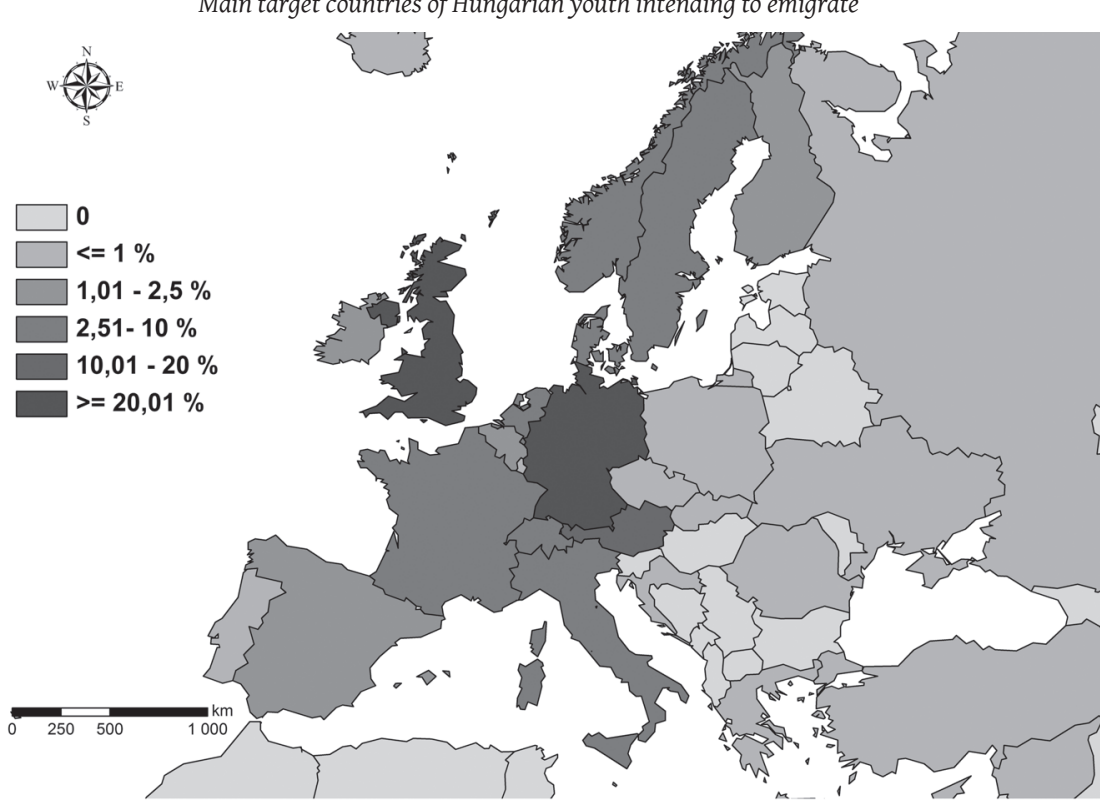

Negyedik helyezést ért el az Egyesült Államok, amely egyre nagyobb ütemben válik a tanulók és $\mathrm{K}+\mathrm{F}+\mathrm{I}-\mathrm{sz}$ ektorban dolgozók migrációs célországává, emellett az észak-európai jóléti államok részesedése is egyre látványosabb, közülük Svédország és Dánia emelhető ki. Svájc, Hollandia és Franciaország kisebb mértékben kedvelt célországok.

A társadalmi struktúrákat vizsgálva Németországba és Ausztriába nagyobb arányban középfokú iskolai végzettséggel rendelkezők mennek, míg az Egyesült Királyság, az észak-európai jóléti államok a magasabban kvalifikáltak célterületei. Az Egyesült Királyságba eleinte kétkezi munkások érkeztek, őket váltják egyre magasabb arányban magasan képzett magyarok. Németországba az iparban dolgozók, míg Ausztriába a tercier szektorban (döntően az idegenforgalomban és kereskedelemben) állást találók migrálnak (Hárs 2010). A kivándorló fiatalok legfőképp orvostudományi, mérnöki (építész-, építő-, gépész- és agrármérnök), gazdálkodástudományi (pl. turizmus-vendéglátás, nemzetközi kapcsolatok) végzettséggel rendelkeznek.

A magyarországi területi jellegzetességeket vizsgálva a migrációs potenciálban egyértelmủen kirajzolódik a fóváros, illetve a vidék, valamint a funkcióikban erős és sokszínű városok, illetve a rurális terek kisvárosai, falvai közötti dualitás. A településhierarchián lefelé haladva a mobilitás határozottsága, komolysága is fokozatosan csökken. Míg a fővárosban élők 41\%-a nem tervez emigrációt, addig az ország városi lakosságának 45\%-a, a rurális terek lakosainak 44,5\%-a ragaszkodik az itthon maradáshoz. Az elköltözést fontolgató „,bille- 
gők" tagjai között a falvakban lakók szerepelnek legnagyobb arányban (40\%), míg a városok lakosainak 37, a fővárosiak 35\%-át foglalkoztatja az elköltözés gondolata. Legélesebb különbség a határozott, biztos elköltözésben jelentkezik, ugyanis a fóvárosiak 23\%-a döntött a közeljövőben történő migráció mellett, ezzel szemben a falusiaknak „csak” 16\%-a, a városlakóknak pedig 18,5\%-a.

Előbbi arányok bebizonyították a fővárosiak erős emigráció iránti hajlandóságát, nyitottságát. A periféria falvaiban és a kiüresedő funkcióvesztett kisvárosokban a szociálpolitika eszközeivel fenntartott és „befagyasztott” mobilitási csatornák (akár társadalmi státuszcsoportok, akár települések, régiók, országok között) beszűkültek (Kovách 2012). Itthon maradásuk, Magyarországhoz ragaszkodásuk azonban magyarázható szubjektív indokokkal is: a családi, rokoni, baráti kötődés, mezőgazdasági tevékenység végzése, kevesebb számú megbízható és személyes információ a külföldi munkaerőpiacról.

A növekvő volumenű tényeges, egyre hosszabb távra tervezett kivándorlás elsősorban a demográfiai és gazdasági erózió által sújtott ipari szerkezetváltás és az ország gazdasági centrumtérségeitől, a fejlett pólusokként kiemelkedő regionális központoktól távol eső rurális tereket sújtja leginkább (4. ábra). Nógrád és Borsod-Abaúj-Zemplén megye mind az emigrációt latolgatók, mind az ország elhagyása mellett határozott döntést hozók, mind a már elköltözők körében vezető helyen áll, ami a megyék kiüresedéséhez, a kvalifikált fiatalkorú lakosság

4. ábra: A migrációs szándék határozottságának és a 2001-2015 közötti népességszám-változásnak az összefüggései (\%)

Correlation and spatial inequalities concerning migration intention and population change between 2001 and 2015 (\%)

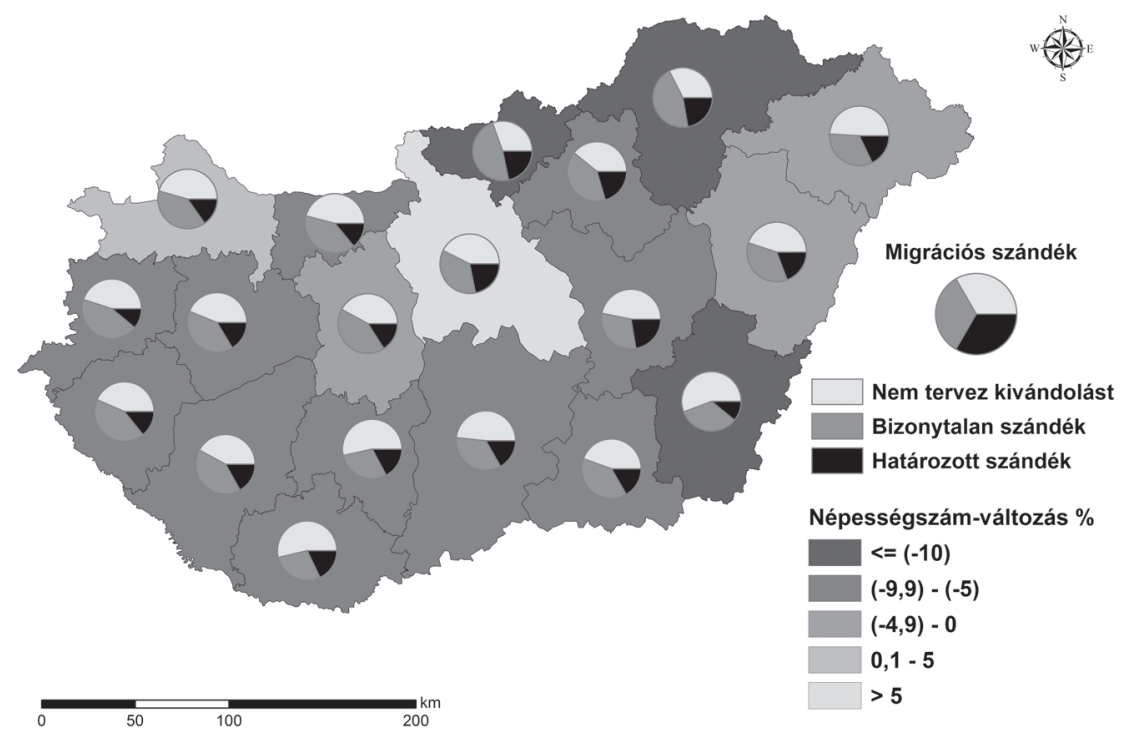

Adatok forrása: saját adatgyüjtés, KSH. 
egyre nagyobb arányú elköltözéséhez, erősödő társadalmi rezidualizációhoz vezet. A gazdasági téren történelmileg erőtlen Észak-alföldi régió mindhárom megyéje kiemelkedik a nagyszámú emigráns, valamint az elköltözés biztos szándékával rendelkező fiatalok tekintetében.

Az eltérések mögötti egyik fontos demográfiai magyarázat az átlagosnál magasabb migrációs potenciál és az érintett megyékben élő romák nagy száma közötti korreláció. A romák végleges elköltözés melletti szándéka négyszer nagyobb a nem romákénál, kétszer nagyobb hajlandóságot mutatnak az azonnali költözés irányába (Bernát 2015; Nyírő 2013). Migrációs potenciáljuk különlegessége, hogy nagy részüknek nincs pontos terve a célországról és a letelepedés pontos forgatókönyvéről, emellett kisebb a külföldi kapcsolati hálójuk.

Az előző megyékkel szemben a társadalmilag és gazdaságilag kedvezőbb adottságú Pest megye és Budapest lakosainak kivándorlási szándékai magyarázatot igényelnek. A megélhetés ellehetetlenülése, a megbecsültség hiánya helyett sokkal inkább az iskolai végzettségnek nem megfelelő munkahely, az oktatási rendszerrel, a pártpolitikával kapcsolatos elégedetlenség, valamint a kiterjedt külföldi kapcsolati tőke, az eddigi szakmai tapasztalatok bősége, a külföldi létről, munkavállalásról származó információk sokasága bátorítólag hat a migrációra. A külföldre költözés napjainkban is elsősorban az alsó középosztály és a középosztály kiváltsága (Hárs 2004), akik nagyobb aránya úgyszintén magasabb a közép-magyarországi térségben.

Leginkább a dél-alföldi és dél-dunántúli megyék fiatalkorú lakossága nem tervezi az ország elhagyását. Rajtuk kívül kiemelendő a nyugat határvidék (Vas, Zala, Győr-Moson-Sopron), ahol szintén az átlagosnál kevesebb számú 40. életévét be nem töltött szándékozik elhagyni az országot. Az említett megyék 1990 óta sokrétü munkahelykínálattal rendelkeznek, így egyrészt az országon belüli kelet-nyugati migráció fó fogadóterületei, másrészt esetükben hangsúlyozandó, hogy az aktív korú lakosság növekvő hányada ingázik napi szinten osztrák és egyre gyakrabban Pozsony környéki szlovák munkahelyekre, oktatási intézményekbe, így ők statisztikailag nem számítanak kivándorlónak.

\section{Összegzés}

Az Európán belüli mobilitási folyamatok vizsgálatai nemzetközi téren a társadalomtudományi kutatások homlokterébe kerültek, az egyre növekvo érdeklődés magas igényeket támaszt az objektív és szubjektív adatok, valamint a migrációt magyarázó társadalmi, gazdasági, politikai, kulturális mechanizmusok bemutatása iránt. A demográfiai válsággal küzdő, sikeres és kevésbé sikeres gazdasági rendszerváltásokon átesett kelet- és közép-európai országok egyre jelentékenyebb szerepet töltenek be a nemzetközi migrációban. Magyarország is annak ellenére, hogy az 1990-es évtizedben fontos fogadó országnak számított, 2000-et követően egyre in- 
kább kibocsátó országgá vált. A magyarok elvándorlásának üteme több évtizedes csúcsokat döntöget, a külföldön dolgozó vagy tanuló magyarok aránya a munkaerőpiac 8-10\%-ára tehető. A magyarok számára az Egyesült Királyság, Németország, Ausztria jelentik a legkedveltebb célországokat, ahol - fóként a nagyvárosokban - akár több ezer fös magyar diaszpórák léteznek. A kivándorlók növekvő arányban a fiatalok közül kerülnek ki, akik egyre gyakrabban választják alternatív életstratégia gyanánt a külföldi továbbtanulást, munkavállalást, családalapítást, karrierépítést. Az országot elhagyók között egyenlő számban találhatóak nők és férfiak, viszont a férfiak között az egyedül szerencsét próbálók felülreprezentáltak, míg a nők rendszeresen párban, családtagokkal közösen költöznek külföldre. A kor előrehaladtával a kivándorlási szándék erőssége csökken, a 21-29 éves korcsoportba tartozók rendelkeznek a leghatározottabb migrációs hajlandósággal.

Elgondolkodtató összefüggés mutatható ki a kivándorlási szándék erőssége és a kint tartózkodás hossza között. A gyenge, bizonytalan szándékú jövőbeni emigránsok elsősorban a rövid és közepes időtávra szóló külföldi tartózkodást preferálják, míg az elköltözésben biztosak az ország hosszú távú, akár végleges elhagyása mellett döntenek. A migrációs hajlandóság szelektív. Általában azok a társadalmi csoportok elhatározása komolyabb, akik körében a lehetőségek (fiatalok, emberi és kapcsolati tőkével rendelkezők), illetve a kényszerek (elégedetlenek, pesszimisták, diszkrimináltak) egymást erősítik. A legfontosabb taszító tényezők évtizedek óta a makrogazdasági és az egyéni szintű anyagi problémák, a megfelelő munkahelyek hiánya. Ezt egészíti ki a politikai élettel való növekvő elégedetlenség, az életkilátások beszűkülése, a bizonytalanság miatti jövővel kapcsolatos félelmek és a társadalmi konfliktusok kiéleződése. A magyar társadalomban a leszakadók, súlyosan depriváltak csoportja egyre markánsabb, ezzel párhuzamosan viszont szúkül a középosztály.

Látványos területi egyenlőtlenségek is jelentkeznek a migrációs hajlandóságot vizsgálva. A határozott és hosszú távra szóló migrációs szándék jelentősebb a gazdaságilag elmaradott térségekben (pl. a szocialista nagyipar egykori fellegvárai, bányászkörzetek, tradicionálisan alulfejlett, határ menti rurális terek, funkciószegény kisvárosok), a magas arányban romák által lakott megyékben. A nyugat-magyarországi megyék fiatalkorú lakossága kevésbé latolgatja a külföldre költözést, viszont az ő megélhetésüket nagymértékben javítják a közeli osztrák munkaerőpiac lehetőségei. Megjelenik egy látványos főváros-vidék, nagyváros-vidék dualitás is: legkomolyabb emigrációs szándékkal a magasan képzett, még független városi fiatalok rendelkeznek.

Négyéves empirikus kutatásaink összesített eredményei alátámasztják a magyar fiatalok évről évre erősödő migrációs hajlandóságát mind a továbbtanulás, mind a munkavállalás terén. A strukturális nehézségekkel (pl. öregedés, csökkenő születések száma) terhelt Magyarország (közel)jövőjének legsürgetőbb megoldandó feladata az ország népességét sújtó elvándorlás megállítása/lassítása, ez azonban kizárólag olyan szakpolitikai lépésekkel, reformokkal lehetséges, amely össztársadalmi szinten - legföképp az alacsonyabb jövedelmi 


\section{státuszúak körében - hosszú távon javítja az életkilátásokat és kiszámíthatóvá teszi a fiatalok jövőjét.}

\section{Jegyzetek}

1 A 2009-ben elfogadott leuveni nyilatkozat alapján 2020-ra az európai felsőoktatási térség végzős hallgatóinak 20\%-ának kell külföldi tanulmányi vagy képzési tapasztalatokkal rendelkeznie.

2 2015-ben 19990 USD - ez az OECD-országok 41153 USD-os átlagos bérének kevesebb, mint fele - volt a magyarok bruttó átlagbére, ennél kedvezőtlenebb értékkel csak Mexikó rendelkezett az OECD-országok közül (http://www.oecd.org/statistics/datalab/bli.htm).

3 A KSH 2014-es Miből élünk? c. felmérésének adatai szerint egy magyarországi háztartásra átlagosan - valamennyi pénzeszközt ideszámítva - 2,9 millió forint megtakarítás jut, de komolyabb pénzügyi vagyonnal csak a háztartások ötöde rendelkezik, a családok 80\%-ának a lakásán és esetleg az autóján kívül nincs számottevő megtakarítása (KSH 2017).

\section{Köszönetnyilvánítás}

A kutatás az OTKA 109449. számú, Legújabb trendek a magyarországi kivándorlásban című 2013 és 2017 között megvalósuló kutatási projekt támogatásával készült.

\section{Irodalom}

Bernát A. (2015): Leszakadóban. A romák társadalmi helyzete a mai Magyarországon. In: A magyar társadalom helyzete és állapota a Nemzeti Társadalmi Felzárkóztatási Stratégia monitoring rendszere alapján. 246-264.

Blaskó Zs., Gödri I. (2014): Kivándorlás Magyarországról: szelekció és célország-választás az „új migránsok" körében. Demográfia, 4., 271-307.

Blaskó Zs., Gödri I. (2016): A Magyarországról kivándorlók társadalmi és demográfiai összetétele. In: Blaskó Zs., Fazekas K. (szerk.): Munkaerőpiaci tükör 2015. MTA Közgazdaság- és Regionális Tudományi Kutatóközpont Közgazdaságtudományi Intézet, Budapest, 59-68.

Blaskó Zs., Sik E., Ligeti A. S. (2014): Magyarok külföldön - Mennyien? Kik? Hol? In: Kolosi T., Tóth I. Gy. (szerk.): Társadalmi Riport 2014. TÁRKI, Budapest, 351-372.

Castles, S., Miller, M. J. (2003): The age of migration. The Guilford Press, New York

Gödri I. (2015): Nemzetközi vándorlás. In: Monostori J., Őri P., Spéder Zs. (szerk.): Demográfiai portré 2015. KSH Népességtudományi Kutatóintézet, Budapest, 187-223.

Gödri I., Feleky G. A. (2013): Elvándorló fiatalok? Migrációs tervek a magyarországi 18-40 évesek körében. KorFA Népesedési Hírlevél, 5., 1-4.

Hárs Á. (2010): Migráció és munkaerőpiac Magyarországon. In: Hárs Á., Tóth J. (szerk.): Változó migráció - változó környezet. MTA Etnikai-nemzeti Kisebbségkutató Intézet, Budapest, 15-55.

Hárs Á. (2011): Magyarok külföldi munkavállalása. Kutatási jelentés. Kopint-TÁRKI Zrt., Budapest

Hárs Á. (2014): A magyar munkaerő-migráció regionális sajátosságairól. Magyar Tudományos Akadémia Közgazdaságtudományi Intézet, Budapest (KTI/IE Műhelytanulmányok; 2004/26.) 
Hárs Á. (2016): Elvándorlás, bevándorlás és a magyar munkaerőpiac. In: Nemzetközi vándorlás, migrációs válság. TÁRKI, Budapest, 243-262.

Hárs Á., Simon D. (2015): A munkaerő-migráció változása a kétezres években Magyarországon. MTA Közgazdaság- és Regionális Tudományi Kutatóközpont, Közgazdaság-tudományi Intézet, Budapest (Budapesti Munkagazdaságtani Füzetek BWP; 2.)

Hárs Á., Simonovits B., Sik E. (2004): Munkaerőpiac és migráció: fenyegetés vagy lehetőség? In: Kolosi T., Tóth I. Gy., Vukovich Gy. (szerk.): Társadalmi riport, 2004. TÁRKI, Budapest, 272-289.

Kiss J. P., Szalkai G. (2014): A foglalkoztatás területi koncentrációjának változásai Magyarországon a népszámlálások ingázási adatai alapján, 1990-2011. Területi Statisztika, 5., 415-447.

Knörr, J. (2000): Women and migration. Anthropological perspectives. Campus Verlag, St. Martin's Press, Frankfurt, New York

Kóródi T., Siskáné Szilasi B. (2016): A XXI. századi magyar populáció migrációs szándékának térbeli vizsgálata. In: Berghauer S. (szerk.): Társadalomföldrajzi kihívások és adekvát válaszlehetőségek a XXI. század Kelet-Közép-Európájában. II. Rákóczi Ferenc Kárpátaljai Magyar Főiskola, Beregszász, 134-141.

Kovách I. (2012): A vidék az ezredfordulón A jelenkori magyar vidéki társadalom szerkezeti és hatalmi változásai. Argumentum, Budapest

KSH (2017) Miból élünk? - A háztartások pénzügyei. Központi Statisztikai Hivatal, Budapest. http://www.ksh.hu/docs/hun/xftp/idoszaki/pdf/mibol_elunk14.pdf(Letöltés:2017.szeptember 24.)

Lee, E. S. (1966): A theory of migration. Demography, 3., 47-57. http://doi.org/b57v76

Massey, D. S., Arango, J., Hugo, G., Kouaouei, A., Pellegrino, A., Taylor, J. E. (1993): Theories of international migration: A review and appraisal. Population and Development Review, 3., 431-466. http://doi.org/fpbvf4

Melegh A. (2002): Magyarország és Németország közötti vándorlás az 1990-es években. In: Illés S., Lukács É. (szerk.): Migráció és statisztika. KSH Népességtudományi Kutató Intézet, Budapest, 53-68. (KSH NKI Kutatási Jelentések; 71.)

Nyírő Zs. (2013): A migrációs potenciál alakulása Magyarországon. Magyar Tudomány, 3., 281-285.

Piore, M. J. (1979): Birds of passage: Migrant labor and industrial societies. Cambridge University Press, Cambridge http://doi.org/bhcw92

Rohr A. (2012): Kivándorlási, külföldi munkavállalási tervek a PTE hallgatóinak körében. Acta Sociologica, 5., 181-190.

Sassen, S. (1988): The mobility of labor and capital: A study in international investment and labor flow. Cambridge University Press, Cambridge http://doi.org/dj8xq8

Sik E. (2015): TÁRKI Monitor- és Omnibusz-felvételek, 2010-2015: Migrációs potenciál Magyarországon 1993-2015. http://www.tarki.hu/hu/news/2015/kitekint/20150511_migracio.html (Letöltés: 2016. június 10.)

Sik E., Örkény A. (2003): A migrációs potenciál kialakulásának mechanizmusa. In: Örkény A. (szerk.): Menni vagy maradni? Kedvezménytörvény és migrációs várakozások. MTA Kisebbségkutató Intézet, Nemzetközi Migrációs és Menekültügyi Kutatóközpont, Budapest, 188-200.

Sik E., Szeitl B. (2016): Migrációs szándékok a mai Magyarországon. In: Blaskó Zs., Fazekas K. (szerk.): Munkaerőpiaci tükör 2015, MTA Közgazdaság- és Regionális Tudományi Kutatóközpont Közgazdaságtudományi Intézet, Budapest, 54-59.

Siskáné Szilasi B., Halász L., Vadnai P. (2017): Az emigráns magyarok életkörülményei, karriertervei, kapcsolati és gazdasági tőkéje. Tér és Társadalom, 4., 148-163. http://doi.org/10.17649/TET.31.4.2892

Sjaastad, A. H. (1962): The costs and returns of human migration. Journal of Political Economy, 70., 80-93. http://doi.org/dsf43t

Todaro, M. P. (1969): A model of labor migration and urban unemployment in less-developed countries. American Economic Review, 59., 138-148.

Vargas-Silva, C. (2017): EU migration to and from the UK. The Migration Observatory at the University of Oxford, Oxford http://www.migrationobservatory.ox.ac.uk/resources/briefings/eumigration-to-and-from-the-uk/ (Letöltés: 2017. október 18.)

Vas A. (2015): Érettségi után irány külföld: magyar diákinvázió a nagyvilágba. Somogyi Hírlap, 2015. február 18.

http://www.oecd.org/statistics/datalab/bli.htm (Letöltés: 2017. szeptember 24.)

http://www.worldaudit.org/democracy.htm (Letöltés: 2017. szeptember 24.) 